\title{
PEMBERIAN MINUMAN HERBAL LEMONGRASS SEBAGAI ALTERNATIF PENATALAKSANAAN NON FARMAKOLOGI MASALAH PSIKOSOSIAL KELOMPOK LANSIA DI WILAYAH KERJA PUSKESMAS NGEMPLAK II SLEMAN YOGYAKARTA
}

\author{
Endang Nurul Syafitri' ${ }^{1,}$ Chistin Wiyani ${ }^{2}$, Muflih ${ }^{3}$, \\ 1,2,3Program Studi Pendidikan Profesi Ners, Program Profesi, Universitas Respati Yogyakarta \\ Email : e.nurul.s@ respati.co.id
}

\begin{abstract}
Abstrak
Maraknya minuman herbal yang dijual bebas di masyarakat sebagai sarana pengobatan alternatif menjadikan tantangan serta sekaligus tujuan bagi tenaga keperawatan dalam peningkatan pelayanan keperawatan. Minuman herbal Lemongrass relatif lebih murah dan aroma serta rasa disukai oleh kelompok lansia dan tidak menimbukan komplikasi karena bukan berupa obat obatan yang dapat mengganggu metobolisme tubuh lansia. Tujuan penelitian untuk pembuktian ilmiah tentang penurunan skor stress dan kecemasan setelah diberikan minuman herbal Lemongrass pada kelompok lansia. Jenis penelitian quasi experiment dengan rancangan penelitian pre test and post test nonequivalent control group design. Teknik pengambilan sampel menggunakan consecutive sampling dengan jumlah sampel 50 orang. Instrumen DASS 42 dengan teknik analisis data menggunakan uji paired sample t-test. Rata-rata kelompok perlakuan sebelum diberikan intervensi dengan nilai mean 15.12 untuk stres, 8.40 untuk cemas, dan median 3.00 untuk depresi. Rata-rata kelompok kontrol sebelum perlakuan dengan mean 12.88 untuk stres, median 9.00 untuk cemas 4.80 untuk depresi. Rata-rata kelompok perlakuan setelah diberikan intervensi dengan nilai mean 11,80 untuk stress, 6.08 untuk cemas, dan 2.00 untuk depresi. Rata-rata stres kelompok kontrol setelah diberikan intervensi dengan nilai mean 12.52 stress, 9.00 untuk cemas, dan 4.56 untuk depresi. Hasil uji pada kelompok intervensi untuk stres, cemas dan depresi didapatkan nilai $\mathrm{p}=0,00(\mathrm{p}<0,05)$. Hasil uji pada kelompok kontrol didapatkan nilai $\mathrm{p}=0,40(\mathrm{p}<0,05)$ untuk stress, $\mathrm{p}=0,94(\mathrm{p}<0,05)$ untuk cemas dan $\mathrm{p}=0,41(\mathrm{p}<0,05)$ untuk depresi. Ada pengaruh pemberian terapi minuman herbal Lemongrass terhadap masalah psikososial lansia di Desa Wedomartani.
\end{abstract}

Kata Kunci : Cemas, Depresi, Lansia, Lemongrass, Minuman herbal, Stres.

\begin{abstract}
Herbal drinks that are sold freely in community, alternative medicine is a challenge as well a goal for nursing improving nursing services. Lemongrass herbal drink is relatively cheaper and the aroma and taste are favored by the elderly and does not cause complications because it is not drug that can interfere with the elderly's body's metabolism. The research objective was to prove scientifically about reduction psychosocial problems scores after given Lemongrass herbal drink. The research is quasi experiment with pre-test and post-test nonequivalent control group design. Consecutive sampling with a sample size of 50 elderly. The DASS 42 instrument with data analysis techniques used paired sample t-test. Mean of the treatment group prior to intervention was 15.12 for stress, 8.40 for anxiety, and 3.00 for depression. Pre-treatment control group mean was 12.88 for stress, median 9.00 for anxiety 4.80 for depression. Mean of the treatment group after being given intervention was 11.80 for stress, 6.08 for anxiety, and 2.00 for depression. Mean stress of the control group after being given the intervention was 12.52 for stress, 9.00 for anxiety, and 4.56 for depression. Result in the intervention group for stress, anxiety and depression obtained $\mathrm{p}$ value $=0.00(\mathrm{p}<0.05)$. Result in the control group obtained $\mathrm{p}$ value $=$ $0.40(p<0.05)$ for stress, $p=0.94(p<0.05)$ for anxiety and $p=0.41(p<0.05)$ for depression. There is an effect of giving Lemongrass herbal drink therapy to the psychosocial problems of the elderly in Wedomartani.
\end{abstract}

Keywords: Anxiety, Depression, Elderly, Lemongrass, Herbal Drinks, Stress. 


\section{PENDAHULUAN}

Usia harapan hidup di Propinsi

Daerah Istimewah Yogyakarta mencapai angka tertinggi di indonesia yaitu 66,28 tahun untuk laki-laki dan 70,25 tahun untuk perempuan. Dalam masalah kesehatan, tidak lepas dari pola penyakit yang berhubungan dengan masalah penuaan seperti penyakit degeneratif, penyakit metabolik, dan gangguan psikososial. Prevalensi lanjut usia yang mengalami stres dan kecemasan belum di ketahui secara pasti. Di Yogyakarta lansia yang mengalami depresi mencapai 5,5\% dan terbanyak pada usia lebih dari 75 tahun mencapai 8,9 \%. Angka kejadian perempuan lebih tinggi yakni 7,4\% dibandingkan laki - laki mencapai 4,7 $\%$ menurut Rikesdas (2018). Sedangkan prevalensi stres di Yogyakarta menurut surve daerah tentang gangguan mental emosional, yang dilakukan oleh Kementrian Kesehatan Daerah Istimewa Yogyakarta, menunjukan prevalensi stres pada lansia adalah 9,6\% (Windarsih, 2017).

Seiring dengan bertambanya usia maka akan terjadi perubahanperubahan yang akan mempengaruhi fungsi dan kemampuan tubuh. Lanjut usia tidak saja ditandai dengan kemunduran fisik, psikososial, tetapi dapat pula berpengaruh terhadap kondisi mental seperti stres. Perubahan psikologis yang paling sering muncul dan sering dialami oleh lansia adalah stress, kecemasan, depresi, insomnia, dan demensia.

Dalam mengatasi masalah dalam perubahan yang di alami lansia perlu dilakukan pemeliharaan kesehatan bagi lansia, salah satunya yaitu dengan minuman herbal lemon gress, fungsi dari lemon gress yaitu lansia di anjurkan untuk mempertahan kualitas hidup karena mengalami perubahan psikis, namun yang harus di perhatikan dalam pemberian minuman herbal pada lansia yaitu janis minuman herbal, takaran atau dosis, dan efek dari minuma herbal tersebut. Manfaat Lemongrass sebagai pengobatan herbal yaitu dapat mengatasi gangguan lambung, susah tidur, gangguan pernapasan, demam, nyeri, infeksi, rematik dan edema. Manfaat mengagumkan dari Lemongrass adalah memiliki kemampuan dalam mengatasi stres, hal ini dikarenakan sifat antidepresan Lemongrass memberikan bantuan untuk mengobati depresi. Rempah ini juga mengaktifkan pelepasan serotonin, zat kimia dalam otak yang berpengaruh terhadap stress, kecemasan dan depresi. Lemongrass terkenal karena efek menenangkan pada pikiran dan tubuh. Minum secangkir Lemongrass, setiap kali merasa tertekan atau memiliki suasana hati yang rendah, aroma wangi dari serai dipercaya bisa menjadi antidepresan, sehingga meminum Lemongrass akan membantu menjadi tetap tenang, mengatasi dan mencegah stress, pikiran kurang bahagia hingga depresi.

Berdasarkan hasil studi pendahuluan yang dilakukan oleh penulis pada Agustus 2020 pada lansia di desa Wedomartani, diketahui lansia yang mengalami masalah psikososial sebanyak 60 lansia Desa Wedomartani. Hasil wawancara dengan 10 lansia, didapat 7 lansia mengatakan sering mengalami susah tidur, gelisah, nafsu makan menurun dan lemas, kemudian 3 lansia mengatakan mudah tersinggung, marah, dan sering merasa pusing. Untuk menghilangkan hal tersebut 6 orang dengan ibadah , 3 orang dengan beraktivitas, dan 1 orang hanya membiarkan begitu saja.

\section{METODE PENELITIAN}

Jenis penelitian quasi experiment dengan rancangan penelitian pre test and post test nonequivalent control 
group design. Teknik pengambilan sampel menggunakan consecutive sampling dengan jumlah sampel 50 orang. Instrumen pada penelitian ini DASS 42. Teknik analisis data menggunakan uji paired sample $t$ test.

Teknik sampling yang digunakan adalah purposive sampling dengan tetap mengacu pada kriteria sampel penelitian. Variable dalam penelitian ini yaitu masalah Psikososial ( Stres, Cemas dan Depresi ) dan minuman herbal Lemongrass. Sampel dalam penelitian ini adalah lansia yang berada di Desa Wedomartani Sleman yang mengalami stress, cemas dan depresi yang terdiri dari : $\quad$ Usia $\geq 60$ tahun, Lansia yang tidak alergi terhadap lemongrass, Lansia yang tidak mempunyai gangguan menelan, Lansia yang tidak menderita penyakit Diabetes Mellitus. Lansia yang bersedia dan memenuhi kriteria diberikan surat informed consent sebagai responden.
Responden dibagi menjadi 2 kelompok yaitu kelompok terapi minuman herbal Lemongrass yang diberikan setiap hari selama 7 hari berturut-turut dan diberikan pada sore hari dan kelompok kontrol.

\section{HASIL PENELITIAN}

Tabel 4.1 Distribusi Frekuensi Jenis Kelamin, Pendidikan, dan Pekerjaan pada Kelompok Perlakuan dan kelompok Kontrol (N=50)

\begin{tabular}{lllll}
\hline Karakteristik & Perlakuan & & Kontrol & \\
\hline Jenis Kelamin & $(\mathbf{f})$ & $\mathbf{( \% )}$ & $\mathbf{( f )}$ & $\mathbf{( \% )}$ \\
\hline Laki-laki & & & 8 & 32 \\
Perempuan & 10 & 40 & 17 & 68 \\
\hline Pendidikan & 15 & 60 & 5 & 20 \\
\hline Tidak Sekolah & & & 13 & 52 \\
SD & 7 & 28 & 2 & 8 \\
SMP & 6 & 24 & 1 & 4 \\
SMA & 4 & 16 & 1 & 4 \\
D3 & 5 & 20 & 3 & 12 \\
S1 & 1 & 4 & & 0 \\
\hline Pekerjaan & 2 & 8 & 0 & 8 \\
\hline Tidak Bekerja & & & 2 & 4 \\
Pensiunan & 5 & 20 & 1 & 52 \\
Wiraswasta & 3 & 12 & 13 & 0 \\
Petani & 3 & 12 & 0 & 4 \\
Buruh & 5 & 20 & 1 & 32 \\
Pedagang & 1 & 4 & $\mathbf{1 0 0}$ \\
IRT & 1 & 4 & $\mathbf{2 5}$ & \\
\hline Jumlah & 7 & 28 & & \\
\hline & $\mathbf{2 5}$ & $\mathbf{1 0 0}$ & & \\
\hline
\end{tabular}

Berdasarkan tabel 4.1 diketahui responden pada penelitian berjumlah 
50 dengan dibagi menjadi 2 kelompok yaitu 25 orang kelompok intervensi dan 25 orang kelompok kontrol. Responden pada penelitian ini adalah lansia dengan sebagian besar berjenis kelamin perempuan, tidak bersekolah dan merupakan ibu rumah tangga.

Tabel 4.2 Skor Stress Sebelum Intervensi pada Kelompok Perlakuan dan kelompok Kontrol $(\mathrm{N}=\mathbf{5 0})$

\begin{tabular}{llll}
\hline Kelompok & Mean & Min & Max \\
\hline Intervensi & 15,12 & 5 & 23 \\
\hline Kontrol & 12,88 & 4 & 19 \\
\hline
\end{tabular}

Berdasarkan tabel 4.2 diketahui bahwa skor stres kelompok perlakuan sebelum 15,12 sedangkan skor stress kelompok diberikan intervensi dengan nilai mean kontrol dengan mean 12,88.

Tabel 4.3 Skor Stress Setelah Intervensi pada Kelompok Perlakuan dan kelompok Kontrol ( $\mathbf{N = 5 0 )}$

\begin{tabular}{llll}
\hline Kelompok & Mean & Min & Max \\
\hline Intervensi & 11,80 & 4 & 20 \\
\hline Kontrol & 12,52 & 3 & 19 \\
\hline
\end{tabular}

Berdasarkan tabel 4.3 diketahui bahwa skor stres kelompok perlakuan setelah diberikan intervensi dengan nilai mean
11,80 sedangkan skor stress kelompok kontrol dengan nilai mean 12,52.

Tabel 4.4 Skor Cemas Sebelum Intervensi pada Kelompok Kontrol dan Intervensi (N=50)

\begin{tabular}{llll}
\hline Kelompok & Mean/Median & Min & Max \\
\hline Intervensi & 8,40 & 4 & 14 \\
\hline Kontrol & 9,00 (Median) & 6 & 16 \\
\hline
\end{tabular}

Berdasarkan tabel 4.4 diketahui bahwa skor cemas kelompok perlakuan sebelum diberikan intervensi dengan nilai mean 8,40 sedangkan skor cemas kelompok kontrol dengan nilai median 9,00

Tabel 4.5 Skor Cemas Sesudah Intervensi pada Kelompok Kontrol dan Intervensi (N=50)

\begin{tabular}{llll}
\hline Kelompok & Mean/Median & Min & Max \\
\hline Intervensi & 6,08 & 1 & 10 \\
\hline Kontrol & $9,00($ Median $)$ & 4 & 18 \\
\hline
\end{tabular}

Berdasarkan tabel 4.5 diketahui bahwa skor cemas kelompok perlakuan setelah diberikan intervensi dengan nilai mean 6,08 sedangkan skor cemas kelompok kontrol dengan nilai median 9,00

Tabel 4.6 Skor Depresi Sebelum Intervensi pada Kelompok Kontrol dan Intervensi (N=50)

\begin{tabular}{llll}
\hline Kelompok & Mean/Median & Min & Max \\
\hline Intervensi & $3,00($ Median) & 2 & 8 \\
\hline Kontrol & 4,80 & 1 & 9 \\
\hline
\end{tabular}

Berdasarkan tabel 4.6 diketahui bahwa skor depresi kelompok perlakuan sebelum diberikan intervensi dengan nilai median 3,00 sedangkan skor depresi kelompok kontrol dengan nilai mean 4,80 
Tabel 4.7 Skor Depresi Sesudah Intervensi pada Kelompok Kontrol dan Intervensi (N=50)

\begin{tabular}{llll}
\hline Kelompok & Mean/Median & Min & Max \\
\hline Intervensi & $2,00($ Median $)$ & 0 & 7 \\
\hline Kontrol & 4,56 & 1 & 10 \\
\hline
\end{tabular}

Berdasarkan tabel 4.7 diketahui bahwa skor depresi kelompok perlakuan setelah diberikan intervensi dengan nilai median 2,00 sedangkan skor depresi kelompok kontrol dengan nilai mean 4,56

Tabel 4.8 Perbedaan Skor Stress Sebelum dan Sesudah Intervensi pada Kelompok Perlakuan dan Kelompok Kontrol

\begin{tabular}{lcccc}
\hline Kelompok & Pre & Post & Beda Mean & P value $(\mathbf{p}<\mathbf{0 , 0 5})$ \\
\hline Intervensi & 15,12 & 11,80 & 3,32 & 0,00 \\
\hline Kontrol & 12,88 & 12,52 & 0,36 & 0,40 \\
\hline
\end{tabular}

Berdasarkan tabel 4.8 hasil uji pada kelompok intervensi didapatkan nilai $\mathrm{p}=0,00 \quad(\mathrm{p}<0,05)$ yang berarti secara statistik terdapat selisih rerata skor stres yang signifikan pada kelompok intervensi sebelum dan sesudah satu minggu pemberian minuman herbal lemongrass. Hasil uji pada kelompok kontrol didapatkan nilai $\mathrm{p}=0,40$ $(\mathrm{p}<0,05)$ yang berarti secara statistik tidak ada perbedaan skor stres secara signifikan pada kelompok kontrol berdasarkan hasil pre test selama satu minggu tanpa pemberian intervensi.

Tabel 4.9 Perbedaan Skor Cemas Sebelum dan Sesudah Intervensi pada Kelompok Perlakuan dan Kelompok Kontrol

\begin{tabular}{|c|c|c|c|c|}
\hline Kelompok & Pre & Post & Beda Mean/Median & P value $(p<0,05)$ \\
\hline Intervensi & 8,40 & 6,08 & 2,32 & 0,00 \\
\hline Kontrol & $\begin{array}{l}9,00 \\
\text { (Median) }\end{array}$ & $\begin{array}{l}9,00 \\
\text { (Median) }\end{array}$ & 0 & 0,94 \\
\hline
\end{tabular}

Berdasarkan tabel 4.9 hasil uji pada kelompok intervensi didapatkan nilai $\mathrm{p}=0,00 \quad(\mathrm{p}<0,05)$ yang berarti secara statistik terdapat selisih rerata skor cemas yang signifikan pada kelompok intervensi sebelum dan sesudah satu minggu pemberian minuman herbal lemongrass. Hasil uji pada kelompok kontrol didapatkan nilai $\mathrm{p}=0,94$ $(p<0,05)$ yang berarti secara statistik tidak ada perbedaan skor cemas secara signifikan pada kelompok kontrol berdasarkan hasil pre test selama satu minggu tanpa pemberian intervensi.

Tabel 4.10 Perbedaan Skor Depresi Sebelum dan Sesudah Intervensi pada Kelompok Perlakuan dan Kelompok Kontrol

\begin{tabular}{lllll}
\hline Kelompok & Pre & Post & $\begin{array}{l}\text { Beda } \\
\text { Mean/Median }\end{array}$ & P value $(\mathbf{p}<\mathbf{0 , 0 5})$ \\
\hline Intervensi & $3,00($ Median$)$ & $2,00($ Median $)$ & 1,00 & 0,00 \\
\hline Kontrol & 4,80 & 4,56 & 0,24 & 0,41 \\
\hline
\end{tabular}

Berdasarkan tabel 4.10 hasil uji pada kelompok intervensi didapatkan nilai $\mathrm{p}=0,00 \quad(\mathrm{p}<0,05)$ yang berarti secara statistik terdapat selisih rerata skor depresi yang signifikan pada kelompok intervensi sebelum dan sesudah satu minggu pemberian minuman herbal lemongrass. Hasil uji pada kelompok kontrol didapatkan nilai $\mathrm{p}=0,41$ $(p<0,05)$ yang berarti secara statistik 
tidak ada perbedaan skor depresi secara signifikan pada kelompok kontrol

\section{PEMBAHASAN}

Terjadinya perubahan skor stress, cemas dan depresi secara umum dapat dikarenakan oleh sifat stresor, durasi stresor, jumlah stresor, pengalaman masa lalu, tipe kepribadian serta koping dan cara pengelolaan stress yang dilakukan. Mumpuni dan Wulandari, (2010) menyatan bahwa menurunkan keresahan dan ketegangan dapat dilakukan dengan menyalurkan hobi atau kegiatan yang menyenangkan meskipun tidak berhubungan langsung dengan stres.

Penggunaan Lemongrass atau biasa disebut serai menjadi suatu produk baru merupakan hal penting sebagai diversifikasi pangan. sitronelol dan geraniol. Sesuai dengan teori (Supriyanto, 2008), kandungan yang terdapat dalam serai adalah minyak atsiri. Berdasarkan penelitian yang dilakukan, kandungan minyak atsiri yang terdapat dalam serai sebesar $0,25 \%$. Hasil pengujian kandungan minyak atsiri yang dilakukan terhadap minuman serbuk serai yaitu sebesar $0,1 \%$. Serai memiliki aroma yang cukup tajam dikarenakan serai mengandung minyak atsiri dengan komponen utamanya sitronelol dan geraniol yang berguna untuk menstabilkan sistem saraf sehingga dapat menimbulkan efek tenang bagi siapapun yang menghirupnya (Watt,Gillian and Janca, Aleksandar, 2008). Lansia mengatakan setelah menghirup aroma dari minuman Lemongrass ia merasa lebih tenang artinya kandungan yang terdapat dalam Lemongrass yaitu sitronelol dan geraniol dapat bekerja menstabilkan saraf.

Dalam penelitian menunjukkan adanya perbedaan stress disetiap perbandingan di hari pertama sampai dengan hari ketujuh. Keberhasilan pemberian berdasarkan hasil pre test selama satu minggu tanpa pemberian intervensi.

aromaterapi dari minuman Lemongrass tidak hanya dipengaruhi kandungan yang terdapat dalam Lemongrass yaitu sitronelol dan geraniol. Didukung dengan ketepatan cara pemberiannya mulai dari kualitas sereh, dosis yang tepat agar tidak menimbulkan efek samping yang ditimbulkan seperti mual dan waktu yang efektif pemberian lemon gress. Pada penelitian ini sampel berjumlah 25 responden yang diberikan minuman herbal Lemongrass sebanyak 7 kali dalam waktu 1 minggu.

Penurunan skor stress, cemas dan depresi pada kelompok kontrol tidak menunjukan adanya perubahan skor yang signifikan. Hal ini disebabkan karena masalah psikologis yang dialaminya seperti stress, cemas dan depresi tidak diatasi dan mendapatkan penanganan yang sesuai, selain itu juga dapat disebabkan oleh cara penanganan yang dilakukan tidak teratur dan waktu, frekuensi atau durasi yang kurang tepat sehingga tidak memberikan pengaruh yang signifikan pada kelompok control. Tidak adanya perubahan skor cemas dan depresi yang signifikan juga dapat disebabkan oleh faktor lain yaitu variabel luar yang tidak dapat dikendalikan oleh peneliti seperti koping, jumlah stresor, sifat stresor, durasi stresor, pengalaman masa lalu, tipe kepribadian, serta penanganan masalah psikososial yang dilakukan oleh masing-masing lansia yang berbeda-beda untuk menghilangkan stress, cemas, dan depresinya.

Setiap lansia juga mempunyai persepsi dan respon yang berbeda-beda terhadap masalah psikososial yang dialaminya. Persepsi seseorang didasarkan pada keyakinan dan norma, pengalaman dan pola hidup, faktor lingkungan, struktur dan fungsi keluarga, tahap perkembangan keluarga, pengalaman 
masa lalu serta mekanisme koping (Purwati, 2012).

Hasil penelitian ini dapat memberikan implikasi keperawatan bahwa terapi dengan minuman herbal khususnya Lemongrass merupakan sebuah bentuk intervensi terapi komplementer yang dapat digunakan sebagai alternatif yang mudah dilakukan untuk mengatasi kondisi masalah psikososial tetapi harus diperhatikan waktu pemberian terapi, faktor-faktor yang dapat menyebabkan masalah psikososial, kondisi lingkungan tempat pemberian terapi, koping, jumlah stresor, sifat stresor, durasi stresor, pengalaman masa lalu, tipe kepribadian, serta bentuk penanganan masalah psikososial yang dilakukan oleh masing-masing lansia.

Penelitian ini menunjukkan bahwa para lansia mengalami penurunan skor stress, cemas, dan depresi setelah mengikuti terapi. Berdasarkan hasil dan penjelasan di atas dapat diambil kesimpulan bahwa terdapat perbedaan skor stress, cemas, dan depresi pre test dan post test pada responden setelah diberikan terapi minuman herbal Lemongrass dengan $p$-value 0,00 cemas dan $p$-value 0,00 untuk depresi $(<0,05)$ yang berarti ada pengaruh yang signifikan terhadap skor stress, cemas, dan depresi para lansia.

\section{KESIMPULAN}

1. Skor stres pada kelompok lansia sebelum diberikan terapi di Desa Wedomartani Sleman dengan nilai mean 15,12 pada kelompok perlakuan sedangkan skor stress kelompok kontrol dengan mean 12,88 .

2. Skor stres pada kelompok lansia setelah diberikan terapi di Desa Wedomartani Sleman dengan nilai mean 11,80 pada kelompok perlakuan sedangkan skor stress kelompok kontrol dengan nilai mean 12,52 .
3. Skor cemas pada kelompok lansia perlakuan dan kontrol sebelum diberikan terapi di Desa Wedomartani Sleman dengan nilai mean 8,40 pada kelompok perlakuan sedangkan skor cemas kelompok kontrol dengan nilai median 9,00.

4. Skor cemas pada kelompok lansia perlakuan dan kontrol setelah diberikan terapi di Desa Wedomartani Sleman dengan nilai mean 6,08 pada kelompok perlakuan sedangkan skor cemas kelompok kontrol dengan nilai median 9,00.

5. Skor depresi pada kelompok lansia perlakuan dan kontrol sebelum diberikan terapi di Desa Wedomartani Sleman dengan nilai median 3,00 pada kelompok perlakuan sedangkan skor depresi kelompok kontrol dengan nilai mean 4,80 .

6. Skor depresi pada kelompok lansia perlakuan dan kontrol setelah diberikan terapi di Desa Wedomartani Sleman dengan nilai median 2,00 pada kelompok perlakuan sedangkan skor depresi kelompok kontrol dengan nilai mean 4,56.

7. Ada pengaruh pemberian terapi minuman herbal Lemongrass terhadap masalah psikososial ( Stres, Cemas dan Depresi ) Lansia di Desa Wedomartani Sleman

\section{SARAN}

Hasil penelitian ini dapat digunakan dalam mengatasi stress, cemas, dan depresi dengan melakukan terapi nonfarmakologi minuman herbal Lemongrass. lansia dapat melakukan terapi ini setiap hari untuk mengatasi stress, cemas, dan depresi.

Bagi keluarga lansia disarankan agar lebih lanjut menindaklanjuti adanya masalah psikososial pada lansia dengan mengenali gejala masalah psikososial pada lansia dan memberikan terapi non 
farmakologi seperti pemberian minuman herbal Lemongrass sebagai cara untuk mencegah terjadinya masalah psikososial lebih lanjut.

\section{DAFTAR PUSTAKA}

Azizah, L. Ma'rifatul. (2011). Keperawatan Lanjut Usia. Edisi pertama. Yogyakarta: Graha Ilmu

Badan pusat statistik Kabupaten Sleman. (2016). Statistik penduduk lanjut usia. Yogyakarta: Badan Pusat Statistik. ISSN: 2086-1026. http://Badan.pusat.statistik//2016 . Diakses tanggal 12-11-2018.

Barua A, Ghosh MK, Kar N, Basilio MA (2011). Prevalence of depressive disorders in the elderly. Ann Saudi Med ; 31(6): 620-624

Crawford, JR \& Henry, JD. (2005). The Depression Anxiety Stress Scale (DASS): Normative dana and latent structure in a large non-clinical sample. British Journal of Clinical Psychology (2005), 42, 111-113.

Depkes RI. (2018). Populasi Lansia Diperkirakan Terus Meningkat Hingga Tahun 2020. Jakarta: Pusat Komunikasi Publik. http://www.depkes.go.id/pdf.php ?id=13110002. Diakses tanggal 12 April 2019.

Dinas Kesehatan Kabupaten Sleman. (2018). Profil Kesehatan Kabupaten Sleman Tahun 2018. Diunduh dari https://dinkes.slemankab.go.id/w pcontent/uploads/2018/09/PROFI L-KESEHATAN-2018-1.pdf pada tanggal 10 Januari 2019.
Damanik, E, D. (2006). Pengujian Realibilitas, Validitas Analisis Item dan Pembuatan Norma DASS.

https://eprints.lib.ui.ac.id/15253/ 1/94859\%2DPengujian\%20reabi litas\%2DFull\%20Text\%2017892 2.pdf. Diakses pada 18 April 2019.

Judha, Mohammad \& Syafitri E. Nurul. (2018). Efektivitas Pemberian Aromaterapi Lemon Terhadap Kecemasan Pada Lansia Di Unit Pelayanan Lanjut Uisa Budi Dharma, Umbulharjo Yogyakarta. Jurnal Keperawatan Respati Yogyakarta. UNRIYO: Yogyakarta.

Kemenkes RI. (2018). Hasil Utama Riskesdas 2018. Diakses tanggal 11

April

2019.http://www.depkes.go.id/re sources/download/infoterkini/ma teri_rakorpop_2018/Hasil\%20Ri skesdas\%202018.pdf

Miller, C. A. (2012). Nursing for Wellness in Older Adults. Philadelphia: Lippincott Williams \& Wilkins.

Sari, Septiana \& Widyaningrum, N. Rahma. (2016). Pengaruh Aromaterapi Minyak Sereh (Cymbopogon citratus) Terhadap Pencegahan Postpartum Blues Pada Ibu Primipara Di RSUD Kabupaten Sukoharjo. Poltekkes Bhakti Mulia Sukoharjo: Jawa Tengah. Diakses tanggal 11 April 2019.

https://docplayer.info/72123976Ijms-indonesian-journal-onmedical-science-volume-5-no-1januari-2018.html 